\title{
Pemecatan Anggota Partai Politik Karena Menjadi Pengurus Organisasi Kemasyarakatan
}

\author{
Gusti Agung Putri ${ }^{1}$
}

1Fakultas Hukum Universitas Udayana, E-mail: putriarimbawa27@gmail.com

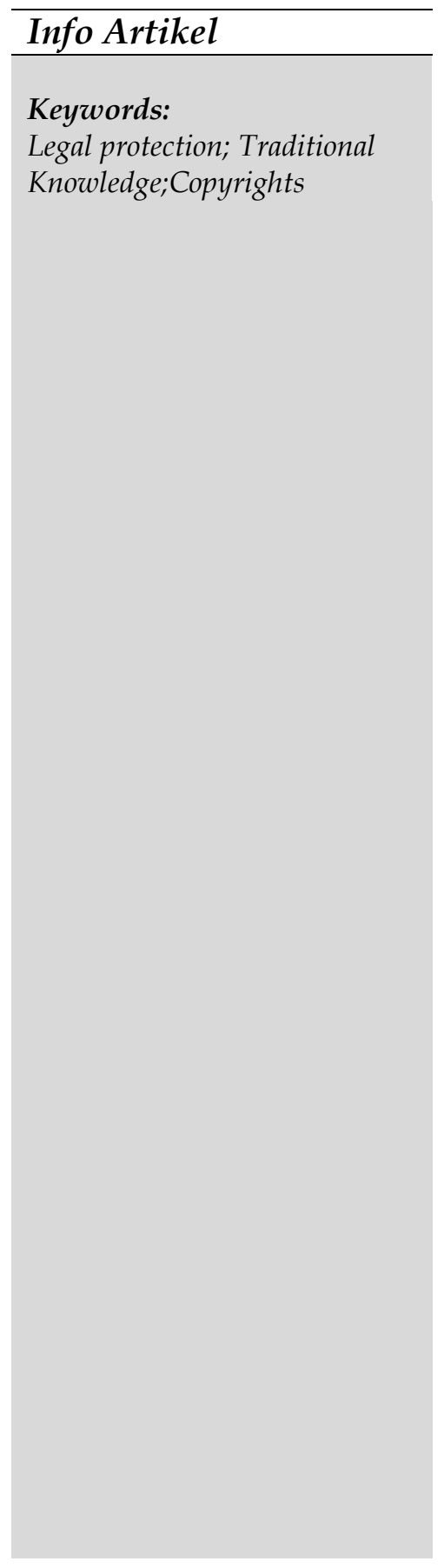

\begin{abstract}
Members of have the right submitted by political parties as candidates for Legislative Assembly in accordance with what is meant by article 12 of Law Number 2 of 2008 jo Law Number 2 of 2011, that political parties have the right to nominate candidates to fill the membership of the Nation Assembly and the Regional Local Assembly in accordance with the legislation; propose a change of time between its members in the Nation Assembly and the Local Assembly in accordance with the legislation. Instead members of political parties must submit and comply with the provisions in Law No. 2 of 2008 jo Law No. 2 of 2011 and the articles of association and bylaws of political parties, accompanied by good sanctions from Law No. 2 of 2008 jo Law No. 2 of 2011 and sanctions on political party organizations. This means that members of a political party can be dismissed from their membership if they become members of other political parties. Substitution between time as a member of the House of Representatives is permitted as long as the interim replacement is in accordance with the prevailing laws and regulations, including participating as members of other Political Parties. Ishak Liputo is listed as the administrator of the Democratic National Community Organization which is not listed as a political party, but Isaac Liputo was replaced through a replacement between times because he was the administrator of a community organization. But in this case Ishak Liputo was fired because he had previously served as administrator of the National Democratic Community Organization before the Organization was officially inaugurated as a Political Party. Research shows the dismissal of Isaac Liputo from membership of the Golongan Karya Political Party because of being the administrator of the National Democratic Community Organization (Nasdem) in terms of Law No. 2 of 2008 jo Law No. 2 of 2012 concerning Political Parties is not appropriate, because: Ishak Liputo became the administrator of the Nasdem Mass Organization, which has not been in the form of a party, so it cannot be said to be a member of a political party. Liputo when warned by the Golkar Party's Management of his actions as a Nasdem administrator, has resigned, so he is no longer a Nasdem administrator.
\end{abstract}




\section{Kata kunci:}

Perlindungan hukum;

Pengetahuan Tradisional;Hak cipta

Corresponding Author:

Agus Kurniawan, E-mail: aguskurniawan2015@gmail.com

DOI:

10.24843/AC.2018.v03.i02.p12

\begin{abstract}
Abstrak
Anggota partai politik mempunyai hak untuk diajukan oleh Parpol sebagai calon anggota DPR sesuai dengan yang dimaksud oleh Undang-undang, bahwa Parpol berhak mengusulkan pergantian kadernya di DPR dan maupun DPRD Sebaliknya anggota partai politik harus tunduk dan patuh pada ketentuan-ketentuan dalam UU dan anggaran dasar maupun anggaran rumah tangga Parpol, disertai dengan sanksi baik dari UU maupun sanksi organisasi Parpol. Hal ini berartri anggota Parpol dapat diberhentikan dari keanggoataannya apabila menjadi anggota Parpol lainnya, Penggantian antar waktu sebagai anggota DPR. Sebagai anggota DPR Ishak Liputo tercatat sebagai pengurus Organisasi Kemasyarakat Nasional Demoktar yang tidak tercatat sebagai partai politik, namun Ishak Liputo diganti melalui penggantian antar waktu karena menjadi pengurus organisasi kemasyarakatan. Tetapi dalam kasus ini Ishak Liputo di pecat karena telah sebelumnya menjabat menjadi pengurus Organisasi Kemasyarakatan Nasional Demokrat sebelum Organisasi tersebut diresmikan menjadi sebuah Partai Politik. Penelitian menunjukan pemecatan Ishak Liputo dari keanggotaan Partai Politik Golongan Karya karena menjadi pengurus Organisasi Kemasyarakatan Nasional Demokrat (Nasdem) ditinjau dari UU Parpol adalah tidak tepat, dikarenakan: Ishak Liputo menjadi pengurus Organisasi Massa Nasdem, yang belum berbentuk partai, sehingga tidak dapat dikatakan sebagai merangkjap menjadi anggota partai politik. Liputo ketika diperingatkan oleh Pengurus Partai Golkar atas tindakannya menjadi pengurus Nasdem, telah mengundurkan diri, sehingga tidak lagi menjadi pengurus Nasdem.
\end{abstract}

\section{Pendahuluan}

Ishak Liputo tercatat sebagai Anggota Partai Golongan Karya dengan Nomor Keanggotaan : 32.020.000.006; Kota Gorontalo, Propinsi Gorontalo. Pada hari Sabtu tanggal 27 Agustus 2011 menerima sebuah surat dari Dewan Pimpinan Pusat Partai Golongan Karya yaitu pada tanggal 16 Agustus 2011 perihal pemberhentian sebagai Anggota parpol golkar atas nama Ishak Liputo (Penggugat). Lahirnya SK dari DPPP Golkar tersebut didasari oleh adanya surat usulan dari Dewan Pimpinan Daerah Partai Golongan Karya Provinsi Gorontalo tentang pemberian sanksi organisasi berupa pemberhentian sebagai Anggota Partai Golongan Karya atas nama Ishak Liputo berdasarkan hasil rapat pleno DPD Partai Golongan Karya Propinsi Gorontalo tertanggal 09 Agustus 2011, serta surat DPD Partai Golkar Propinsi Gorontalo Nomor 197/DPD/-GOLKAR/PROV-GTLO/VII/2011 tanggal 10 Agustus 2011 perihal laporan dan permohonan pemberhentian Ishak Liputo sebagai Anggota Partai Golongan Karya. 
Surat peringatan I Nomor : 273/DPD-GOLKAR/ GTLO/XII/2010 tanggal 20 Desember 2010 tentang larangan keikutsertaan pengurus fungsionaris/kader Partai Golkar pada Organisasi Kemasyarakatan Nasional Demokrat (Nasdem). Sebagai bentuk loyalitas selaku kader / anggota Partai Golkar maka sebelum menerima teguran I dan Teguran II tersebut sudah secara resmi membuat, menyatakan serta mengirimkan surat pengunduran diri dari kepengurusan ormas Nasdem Propinsi Gorontalo tanggal 18 Nopember 2010 yang ditujukan langsung kepada Ketua Wilayah Nasdem Propinsi Gorontalo serta disusul lagi surat Penggugat tanggal 27 Desember 2010 (tentang klarifikasi) yang ditujukan langsung kepada Ketua DPD I Partai Golongan Karya Propinsi Gorontalo. Dengan demikian maka sangat tidak berdasar hukum jika melanjutkan surat peringatan tersebut pada tahap berikutnya (surat peringatan ke-2). Nasdem ketika itu belum berbentuk partai politik melainkan masih berbentuk organisasi kemasyarakatan Nasdem dan setelah mendapat peringatan Ishak Liputo langsung mengajukan pengunduran diri dari Ormas Nasdem, namun pemecatan sebagai anggota Partai Golkar terhadap Ishak Liputo masih berlanjut.

Ishak Liputo menyelesaikan permasalahan pemecatan dari Partai Golkar tersebut melalui jalur hukum dengan menggugat Partai Golkar. Bagian Pendahuluan ditulis secara jelas yang memuat latar belakang permasalahan yang memadai, permasalahan yang dikaji, tujuan penulisan, serta state of the art dari penelitian maupun publikasi sebelumnya, sebagai pembuktian bahwa artikel yang diajukan memiliki orisinalitas serta mempunyai kontribusi baru bagi sumbangan keilmuan yang penting untuk dipublikasikan. ${ }^{2}$

\section{Metode Penulisan}

Karena kajian ini berfokus dan berangkat dari kekaburan norma, menggunakan pendekatan: statute approach, conceptual approach, serta analytical approach. ${ }^{3}$ Tehnik penelusuran bahan hukum menggunakan tehnik studi dokumen, serta analisis kajian menggunakan analisis hukum. metode penelitian yang digunakan berupa penelitian hukum normatif, dimana merupakan penelitian yang didasarkan pada norma yang berlaku sebagai acuan utamanya,serta pada akhirnya bahan-bahan hukum tersebut disistematisasikan. Pada langkah analisis, guna memperoleh suatu jawaban maka akan digunakan penalaran deduktif, serta dalam menjawab permasalahan tersebut digunakan penafsiran sistematis.

\footnotetext{
2Jurnal Magister Hukum Udayana menggunakan penulisan model APA (American Psychological Association)Citation Style. Contoh: Bossche, P.V.D. (2008). The Law and Policy of the World Trade Organization: Text, Cases and Materials. New York:Cambridge University Press, p. 332-335

${ }^{3}$ Metode penelitian hukum normatif relevan diterapkan pada pengkajian hukum yang mengandung problematika norma kabur, norma kosong maupun norma konflik. Lihat Diantha, I. M. P. (2016). Metodologi Penelitian Hukum Normatif dalam Justifikasi Teori Hukum. Prenada Media.h. 12.
} 


\section{Hasil Dan Pembahasan}

Ishak Liputo adalah salah satu anggota Partai Golongan Karya tercatat dengan Nomor Keanggotaan : 32.020.000.006; Kota Gorontalo, Propinsi Gorontalo. Pada hari Sabtu tanggal 27 Agustus 2011 Ishak Liputo menerima sebuah surat dari Dewan Pimpinan Pusat Partai Golongan Karya yaitu SK DPPPPartai Golkartertanggal 16 Agustus 2011 tterkait pemberhentian sebagai Anggota Partai Golongan Karya atas nama Ishak Liputo. Ishak Liputo menolak pemecatan tersebut yang berarti pada Partai Golkar terjadi perselisihan internal partai. Dikatakan terjadi perselisihan internal partai karena yang terjadi sebagaimana penjelasan pasal 32 UU Parpol Tahun 2011, tentang kepengurusan, maupun pelanggaran terhadap hak anggota Partai Politik ataupun pemecatan tanpa alasan yang jelas.

Ishak Liputo oleh pengurus Partai Golkar diberhentikan dari keanggotaan partai dengan alasan menjadi pengurus organisasi massa Nasdem dengan alasan tidak loyal dengan partai. Ketika pengurus memberikan surat peringatan Ishak Liputo telah mengundurkan diri dari kepengurusan organisasi massa Nasdem, dan ketika itu Nasdem masih dalam bentuk organisasi massa belum berbentuk partai. Meskipun demikian pengurus Partai Golkar tetap memecat Ishak Liputo sebagai anggota partai, sehingga terjadi sengketa internal Parpol Golkar dalam kasus Ishak Liputo tidak dilakukan sesuai dengan prosedur hukum yang berlaku, karena hanya dilakukan sesuai dengan kebijakan partai bukan dilakukan dengan cara-cara jika di internal Parpol tidak ada penyelesaian harus diajukan ke Pengadilan Negeri. Penyelesaian pemecatan Ishak Liputo dari Partai Golkar dilakukan oleh mahkamah Partai Politik atau sebutan lain yang dibentuk oleh Partai Politik. Susunan mahkamah Partai Politik atau sebutan lain disampaikan oleh Pimpinan Partai Politik kepada Kementerian. Penyelesaian perselisihan internal Partai Politik harus diselesaikan paling lambat 60 (enam puluh) hari. Putusan mahkamah Partai Politik atau sebutan lain bersifat final dan mengikat secara internal dalam hal perselisihan yang berkenaan dengan kepengurusan dapat dijelaskan bahwa pemecatan Ishak Liputo dari keanggotaan Partai Golkar adalah cacat hukum, karena tidak ditempuh sesuai dengan peraturan perundang-undangan, oleh karenanya dianggap tidak pernah terjadi pemecatan. Apabila kenyataannya Ishak Liputo dianggap bukan lagi sebagai anggota Partai Golkar, maka yang terjadi adalah adanya pelanggaran hak asasi Ishak Liputo. Melanggar hak asasi adalah melanggar hukum.

Berdasarkan pembahasan berkaitan dengan pemecatan Ishak Liputo dari keanggotaan Parpol Golkar karena menjadi pengurus Ormas Nasdem dapat dijelaskan bahwa Ishak Liputo belum dapat dikatakan sebagai merangkap anggota Parpol, karena Nasdem ketika itu belum berbentuk Parpol. Yang dicantumkan dalam Bagian Pendahuluan juga kembali dikaji dan dielaborasi dapada Bagian Hasil dan Pembahasan. Analisis pada bagian Hasil dan Pembahasan dapat didukung dengan Tabel yang disajikan secara horizontal. Penyajian Tabel dilengkapi dengan "Judul Tabel" dan "Sumber Tabel." Setiap Tabel diikuti dengan kajian serta komentar penulis sebagai bagian dari analisis terhadap Tabel yang disajikan. Selain tabel, ketentuan Undang-Undang atau peraturan lainnya yang disajikan dilengkapi dengan kajian dan pendapat penulis dalam memperkuat dan mempertajam analisis artikel yang diajukan untuk 
dipublikasikan. ${ }^{4}$ Pemecatan sebagai anggota Partai Golkar menimbulkan suatu perselisihan internal partai karena Ishak Liputo menolak pemecatan tersebut, namun Partai Golkar berdasarkan kebijakan partai menerbitkan Surat Keputusan Pemecatan, yang berarti tindakan pengurus partai tidak sesuai dengan ketentuan pasal $32 \mathrm{UU}$ Parpol, namun kenyataannya MA yang telah memeriksa pada tingkat kasasi sebagaimana putusan nomer364K/Perdata.Sus/2012, yang mengesahkan pemecatan Ishak Liputo dari keanggotaan Partai Politik Golongan Karya karena menjadi pengurus Organisasi Kemasyarakatan Nasional Demokrat (Nasdem) ditinjau dari UU Parpol, yang berarti Mahkamah Agung telah membenarkan pemecatan Ishak Luputo dari Partai Golkar.

\section{Kesimpulan}

Putusan Mahkamah Agung Nomor 364K/Perdata.Sus/2012, yang mengesahkan pemecatan Ishak Liputo dari keanggotaan Partai Politik Golongan Karya karena menjadi pengurus Organisasi Kemasyarakatan Nasional Demokrat (Nasdem) ditinjau dari UU Parpol tentang Partai Politik adalah belum tepat, dikarenakan:

- Ishak Liputo menjadi pengurus Organisasi Massa Nasdem, yang belum berbentuk partai, sehingga tidak dapat dikatakan sebagai merangkjap menjadi anggota partai politik.

- $\quad$ Ishak Liputo ketika diperingatkan oleh Pengurus Partai Golkar atas tindakannya menjadi pengurus Nasdem, telah mengundurkan diri, sehingga tidak lagi menjadi pengurus Nasdem.

- Ishak Liputo diberhentikan dari pengurusan Partai Golkar oleh pengurus partai, sehingga terjadi perselisihan internal partai Golkar, dan tidak diselesaikan melalui suatu mahkamah Parpol atau sebutan lain yang dibentuk ecara intern oleh Parpol.

- Penyelesaian sengketa internal Parpol Golkar tidak dilakukan sesuai dengan prosedur hukum yang berlaku melainkan hanya didasarkan atas kebijakan partai Golkar.

\section{Ucapan terima Kasih (Acknowledgments)}

Pada penulisan Tesis ini saya ingin mengungkapakan rasa terima kasih yang sebesarbesarnya atas semangat, motivasi, dorongan, dan bantuan, serta inspirasi kepada, semua pihak baik ecara individu maupun kedinasan yang telah mensupport, membantu kelancaran dalam penulisan tesis ini, mulai dari dosen penguji, pembimbing maupun seluruh staff TU fakultas hukum universitas Udayana. Khususnya saya mengucapkan terimakasih sebesar besarnya terhadap Keluarga yang tidak pernah lelah membimbing, menasehati, membantu, dan terus memotivasi saya dalam mengerjakan Tesis ini baik dari segi moril, materiil, maupun spiritual sehingga saya dapat menyelesaikan Tesis ini dengan baik.Akhir kata, saya mengucapkan terima kasih pada semua pihak yang telah membantu saya dalam menyelesaikan penulisan ilmiah ini. Semoga Tesis ini dapat memberikan manfaat dan wawasan kepada semua pihak yang membacanya.

${ }^{4}$ World Trade Organization. Understanding the WTO Agreement Intellectual Property and Enforcement. Available from https://www.wto.org/english/thewto_e/whatis_e/tif_e/agrm7_e.htm. (Diakses 5 Mei 2018). 


\section{Daftar Pustaka / Daftar Referensi}

Philipus M. Hadjon, Kedaulatan Rakyat, Negara Hukum dan Hak-hak Asasi Manusia, Kumpulan tulisan dalam rangka 70 tahun Sri Somantri Martosoewignjo, Media Pratama, Jakarta, 1996

Ni Ketut Supasti Dharmawan. Keberadaan Pemegang Saham dalam Rups Dengan Sistem Teleconference Terkait Jaringan Bermasalah dalam Perspektif Cyber Law, Jurnal Magister Hukum Udayana (Udayana Master Law Journal), Vol. 4, No. 1, Edisi April. 2015, https://ojs.unud.ac.id/index.php/jmhu/article/view/13051, diakses tgl 9 Juli 2018.

DITAYANI, Putu Eva. KEWENANGAN PEMBUBARAN PARTAI POLITIK OLEH MAHKAMAH KONSTITUSI DITINJAU DARI PERSPEKTIF HAK ASASI MANUSIA (HAM). Jurnal Magister Hukum Udayana (Udayana Master Law Journal), [S.1.], v. 3, n. 3, nov. 2014. Date accessed: 15 aug. 2018.

BUDIYANTO, Bambang. KEWENANGAN PIMPINAN PARTAI POLITIK DALAM PENGUSULAN PEMBERHENTIAN ANGGOTA DPR TERKAIT TINDAK PIDANA KORUPSI. Jurnal Magister Hukum Udayana (Udayana Master Law Journal), [S.1.], v. 5, n. 4, Date accessed: 15 aug. 2018.

Jurnal Magister Hukum Udayana menggunakan penulisan model APA (American Psychological Association)Citation Style. Contoh : Bossche, P.V.D. (2008). The Law and Policy of the World Trade Organization: Text, Cases and Materials. New York: Cambridge University Press.

Metode penelitian hukum normatif relevan diterapkan pada pengkajian hukum yang mengandung problematika norma kabur, norma kosong maupun norma konflik. Lihat Diantha, I. M. P. (2016). Metodologi Penelitian Hukum Normatif dalam Justifikasi Teori Hukum. Prenada Media.

Ni Ketut Supasti Dharmawan. Keberadaan Pemegang Saham dalam Rups Dengan Sistem Teleconference Terkait Jaringan Bermasalah dalam Perspektif Cyber Law, Jurnal Magister Hukum Udayana (Udayana Master Law Journal), Vol. 4, No. 1, Edisi April. 2015, https://ojs.unud.ac.id/index.php/jmhu/article/view/13051, diakses tgl 9 Juli 2018.

Rudiani, Ni Kadek, Pengaruh Amandemen Keempat Undang-Undang Dasar Negara Republik Indonesia Tahun 1945 Terhadap Pemerintahan Daerah. Jurnal Magister Hukum Udayana (Udayana Master Law Journal), V. 6, N. 1, Edisi Okt 2017, https://ojs.unud.ac.id/index.php/jmhu/article/view/34575, diakses tgl 8 Juli 2018.

Karma Resen, Made Gde Subha, Ovasi Daerah (Refleksi dan Pengaturan Inovasi Daerah di Indonesia), Jurnal Magister Hukum Udayana (Udayana Master Law Journal), $\mathrm{V}, \quad 4, \quad \mathrm{~N}$ 4, Edisi Des, 2015,https://ojs.unud.ac.id/index.php/jmhu/article/view/18745, diakses tgl 8 Juli 2018. 
P-ISSN: 2502-8960, E-ISSN: 2502-7573

Susila, I Nyoman Adi, Pengaturan Kawasan Suci Pantai Dalam Penyediaan Sarana Wisata Tirta Di Provinsi Bali. Jurnal Magister Hukum Udayana (Udayana Master Law Journal), V. 6, N. 4, Edisi Des. 2017, https://ojs.unud.ac.id/index.php/jmhu/article/view/37069, diakses tgl 8 Juli 2018. 